the north in a spur of the Datchworth outlier. So gradual, it was noticed, has been the dissolution of the Chalk and its replacement by the superincumbent strata, that the position of a band of flints passing across the pipe has not been disturbed.

\title{
REFERENCES.
}

Geological Survey Map, Sheet 46, B.E.

Elsden, J. V.-“The Post-tertiary Deposits of Hertfordshire.” "Trans. Herts. Nat. Hist. Soc.,' Vol. i, part 3, pp. 103-112

Hopkinson, J.- " Field Meeting at Tewin Water, Digswoll, and Ayot Green, Welwyn.” 'Trans. Watford Nat. Hist. Soc.' Vol. ii, part 7, pp. lvi.lviii.

Hughes, Prof, P. McK.- "The two Plains of Hertfordshire and their Gravels.” 'Quart. Journ. Geol. Soc.,' Vol. xxiv, pp. 284.286.

Pryor, R. A.- "On the . . Medicinal Waters in Herts." Trans. Watford Nat. Hist. Soc.,' Vol. i, pp. 110, 111.

Writaker, W.-“Geology of the London Basin." 'Mem. Geol. Surv.,' Vol. iv, p. 237.

Woon, S. V., Jun.-_" On the Pebble-beds of Middlesex, Essex, and Herta." 'Quart. Jonrn, Geol. Soc.,' Vol. xxiv, p. 468.

\section{EXCURSION TO WALTON COMMON AND ST. GEORGE'S HILL.}

\section{Saturday, Max 29th, 1886.}

Director: W. H. HodLmston, F.R.S., Sec. G.S.

\section{(Report by The DirhCTOR).}

This was a half-day's Excursion, the party arriving at Walton Station shortly after 2 p.m., where they were joined by the Director. The main object of the Excursion, as stated in the Circular, was to study some sections recently described before the Geological Society, the details of which may be found in the 'Q. J. G. S.,' Vol. xliii, p. 147 (May, 1886). These sections had been exposed in consequence of the widening of the London and South-Western main line between Walton and Weybridge.

It was arranged that the party should walk along the line as far as Haines' Bridge, in Upper Weybridge, a distance of about it miles; and to effect this in safety every facility was afforded by the officers of the Company. The resident engineer, Mr. Oswald M. Prowse, F.G.S., a Member of the Association, accompanied 
the party, who were greatly indebted to him for having had some of the more critical points cleared of the rubbish which had accumulated during the winter and the spring, and also for other precautions, such as the cutting of steps, \&c.

The first point of interest occurs at the end of Block $A$. (see diagram annexed), where a considerable mass of buff-coloured, false-bedded sand, more or less underlain by gravel, abuts against a steep surface of London Clay. This sand is mapped in the 'Geology of London and its Environs' as Lower Bagshot in situ. The members were invited to act as a jury in the matter, and to decide whether this peculiar mass should not be regarded as forming part of the "mixed gravel" series in the manner indicated by the Director. At the time of the visit there was more obscurity about the section than when it was first seen, but the general feeling was in favour of regarding it as a superficial deposit.

Since the date of the Excursion the slope has been cut back about 10ft., and, through the vigilance of Mr. Prowse, the Director had an opportunity (July 22nd) of inspecting the section when it was quite fresh. It was then seen that $7 \mathrm{ft}$. of gravel intervenes between the false-bedded sand and the steep slope of the London Clay. This places the superficial character of the sand beyond a doubt, and there are reasons for supposing that this sharp rise of London Clay at the corner represents the margin of the Mole valley inlet in Quaternary times.

The next point for the jury to decide was the nature of the grey sandy clay (block B. of the diagram), which was regarded by the Director as London Clay, but which is mapped as Lower Bagshots in sheet No. 8 of the Geological Survey. To many a search this exposure of grey clay, nearly 400 yards in length and in some places about $18 \mathrm{ft}$. deep, had yielded no trace either of septaria or of fossils, and it was just whispered that the mass might represent an argillaceous phase of the Lower Bagshots. The Director pointed out that Prof. Prestwich, in his classical papers ('Q. J. G. S.,' Vol. iii.), clearly regarded this mass as London Clay, since he speaks of it as being succeeded conformably by the Bagshot beds at this very place. The jury set to work diligently to find any fossil or other evidence as to the nature of these beds, which in truth would have been set down without the least hesitation as London Clay if they had not been mapped as Bagshots. One of the Members was fortunate enough to find the fragment of a poly- 


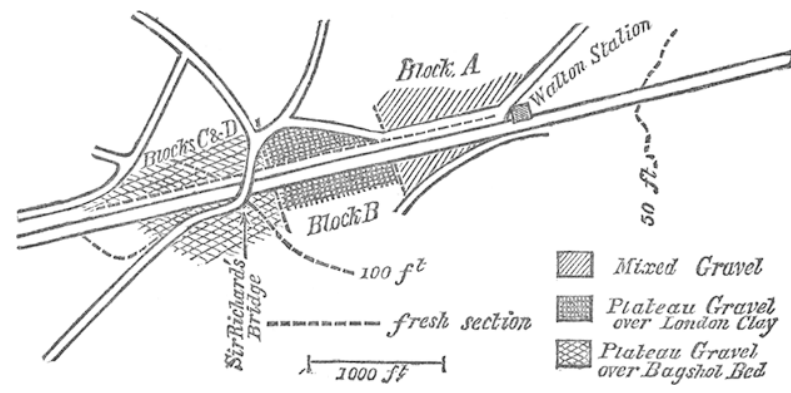

FIG. I.-Sketch-Map, showing the position of the section at Walton.

W.S.W. Bridge.

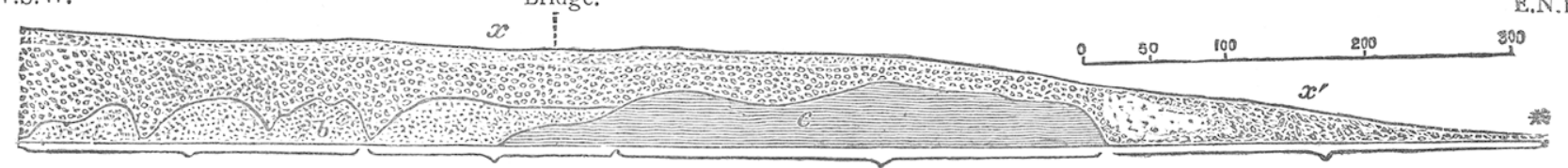

FIr. 2.-Generalized Section of the Cutting through Walton Common, September to December, 1885 .

Total length ro7o yards : maximum depth about 27 feet. Depth at the Bridge 24 feet.

Block A extends from Walton Station to where the unaltered London Clay is seen to occur in situ, a distance of 313 yards.

Block B extends from this to the point where the Bagshot Beds are first seen in situ, a distance of 345 yards.

Block $\mathrm{O}$ extends from the above to the point where the Bagshots are first cut through to the level of the line, and the hollow filled up with Plateau-

Block D exhibits the relations of the Bagshots to the Plateau-gravel, where the latter is most fully developed, a distance of 247 yards.
* Walton Station.
$b$ Bagrshot Beds.
$x$ Plateau Gravel.
$x^{\prime}$ Mixed Gravel.
Scale-300 yards.
c London Clay.

(Both diagrams by permission of the Council of the Geological Socieiy.) 
zoan, which he entrusted to Mr. Chas. D. Sherborne, who was present, for determination. That gentleman submitted the specimen to Mr. G. R. Vine, who regards it as probably identical with Membranipora Lacroixii (Busk), a fossil known to occur in the London Clay of Colwell Bay. Specimens, according to Mr. Vine, from Highgate, Colwell Bay, and Walton Common, are very similar as regards the oval outline of cell, differences in size being considered as of less importance.

The party then moved on to Sir Richard's bridge, where the junction of the London Clay with the Lower Bagshots was so well seen a few months ago. The works in connection with the bridge, and the sliding over of the superincumbent gravel, had considerably impaired the clearness of the section, although Mr. Prowse did his best to have a fresh face cut for inspection on the present occasion. Tbis is the most interesting and crucial point exposed in the entire cutting. Nowhere perhaps is there a better junction between London Clay and undoubted Lower Bagshots to be seen, and the question of conformability or unconformability was eagerly discussed by the jury. The striking false-bedding and irregular development of the bright yellow sand which succeeds the evenlybedded grey sandy clay, at once arrests the attention, and this is further fixed by a very miscellaneous band, chiefly of blue clay, which intervenes between the basement bed and the ordinary Lower Bagshots of the district. On the whole there was a fairly general concensus of opinion that there is an unconformity at this place between the two formations.

Continuing along the line, the great thickness and often very sandy character of the Plateau-Gravel was noticed, and here the Director gave some particulars as to the development and composition of the Walton-Oatlands sheet, which is spread out so widely about the $100 \mathrm{ft}$. contour. The materials are similar to those of sheets occurring at much higher levels, such as the one on St. George's Hill ; and, although at so low an elevation, appear to have nothing in common with the valley-gravels of the district. A fresh section further down the line, in the Oatlands ballast pit, showed a series of $\nabla$-shaped curves, consisting of gravel, sand and loam belonging to this sheet-the whole resting on an irregular surface of Lower Bagshot Sand.

At Haines' Bridge the railway was left, and the party commenced to ascend the slope leading up to St. George's Hill, past 
a rapidly-increasing group of red brick mansions, built amid the pine trees, which are now all the rage in this part of the country. About a mile from the bridge is the brickyard, just below the 200ft. contour, and here a freshly-cut face displayed the contorted series of sands and loams with interspersed flint gravels, which reposes upon the laminated clays occurring at the base of the Middle Bagshots. The merits of the glacial, semi-glacial, and soilcap theories were severally discussed, and there was the usual dispute about "green earth" and "glauconite," both of which enter into the composition of these curious beds. About the junction of the Middle and Lower Bagshots a considerable quantity of carbonaceous matter was noted in one of the excavations at this place.

Some of the more exclusively geological of the party left at this juncture, not caring to face the toils of St. George's Hill, the north end of which is rather less than a quarter of a mile from the brick pits, and about 50ft. higher. The following curious extract from "Murray's Handbook" (1876) may serve to account for certain erroneous notions respecting this hill :-“"St. George's Hill, the highest point of the Bagshot Sand, is about one mile south of Weybridge Station. . . The hill itself, about 500ft. in height, commands," \&c. It is perfectly true that the views are remarkably fine, and, partly perhaps from the wooded nature of the foreground, the hill appears more lofty than is really the case. It is, in point of fact, a narrow platean rather over a mile in length from north to south, and does not anywhere attain an elevation exceeding $257 \mathrm{ft}$.

The interest of the remainder of the Excursion was chiefly topographical, and the day being very fine and clear after the late rains, the party enjoyed most thoroughly the delightful scenery both far and near. London bears E.N.E., not quite twenty miles to St. Paul's, yet but little trace of that huge city is visible. The valley of the Thames is of great width here in its northward extension across Middlesex, presenting the features of an immense plain. Traced towards the east this great plain, covered with the so-called valley gravel of the Thames, is seen to narrow somewhat, and finally to enter a well-defined valley between the London Clay mass constituting Richmond Hill and the opposing heights of Middlesex. Thus to the spectator on St. George's Hill London proper is hidden by the high ground of 
Richmond Park, and when the wind is westerly, as fortunately on this accasion, but little smoke is noticeable. The north-western suburbs of London creeping up towards Hampstead Church are just uncovered, but all the rest is left to the imagination.

There is so much timber on St. George's Hill that nothing like a panoramic view can be obtained, and thus it is by snatches, as it were, that the features of the distant scenery are revealed. There are some charming peeps in a westerly direction, as, for instance, the glimpse of the Lower Greensand country of Hind Head through the gap in the chalk range at Guildford. These hills are nearly $1,000 \mathrm{ft}$. high, and 20 miles distant. Then there is another charming surprise, where a sudden twist of the umbrageous terrace, on the edge of which the party was walking, directs attention to the north-west, and the stately pile of Windsor Castle seems startlingly near, as seen through the pure air of that very fine afternoon, though in reality 12 miles distant. The western horizon is occupied by the long line of Chobham ridges, a range which divides the Bagshot area of the London basin into an eastern and a western half. The nearest point of these ridges is some 12 miles, and the intervening country seems to be a mass of fir woods, with open heath here and there, the cultivated ground being more or less concealed-a wild-looking region-showing how extremes may meet, when the Tertiary sands of Surrey almost initate in their vegetation the palæozoic rocks of the highlands. Towards the south centre of St. George's Hill a large gravel pit afforded the party an opportunity for studying the Plateau-gravel on the plateau. The surface of this gravel is $140 \mathrm{ft}$. higher than that of the Walton-Oatlands plateau previously described. Hence it is presumably much older. The materials are very similar, especially resembling the less sandy portion of the lower sheet. The Director here made a few observations relative to Plateaugravel of West Surrey, quoting more especially from the writings of Prof. Rupert Jones.

A move was then made in the direction of Cæsar's camp, which occupies the sonth-east scarp of the hill. No donbt "Crsar's camps" are as plentiful as blackberries in the county of Surrey, but the remarkable triangle formed by the one on St. George's Hill, that above Aldershot, and lastly the one at the termination of Easthampstead plain, probably constituted a defensive system in West Surrey even before Cæsar's time. Geologically speaking 
these camps occupy positions of considerable similarity, but this is the genuine article, for the legend on the 6in. Ordnance map tells us that it is the "British camp occupied by Casar before the crossing of the Thames at Cowey Stakes."

A very cursory examination-and the party had time for no more-serves to show that this place is a natural fortress, being, in fact, a small tabular area of about 14 acres in extent, from which three or four steep gorges break away very precipitously, especially on the north-west and sonth-east. The approaches are from the northeast, where the area of the camp merges in the general plateau of St. George's Hill, and here the system of outworks is the most elaborate. On the sontb-west side, too, where the declivities are less sharp, there is a double vallum. These valla or mounds appear to be mainly composed of the Plateau-gravel, and there has been at one time a tendency to mend the roads with the material. The system of northern outworks, besides affording defence on the weakest side, is so arranged as to include a spring of water in the northern gorge. This must have been of great consequence to the occupants, since the question of "what they did for water," when hard pressed on these dry and limited upland tables, has often exercised the military mind. It is probable that a very considerable deposit of Plateau-gravel occurs here, and the water is either thrown out by a pan at the base or possibly by some argillaceous bed of the Middle Bagshots. Hence not only has an accumulation of Platean-gravel determined the sculpturing of these "camps," but in this case it has helped to collect the water for those who were to hold them.

When the Director had made known these things, he invited the party to try the "waters" at the Swiss Cottage, and finally proposed that the meeting should adjourn from the camp of Cosar to the Palace of Henry VIII., at Oatlands Park,* where he hoped to have the honour of entertaining the members. This was acceded to nem. con., but the distance of three miles was rather an infliction for some after so long an afternoon.

A vote of thanks, proposed by the President and seconded by Mr. Holmes, was duly acknowledged by the Director, after which the party broke up, there being very little time to visit the Grotto and other curiosities of Oatlands.

* The Oatlands Park Hotel is not on the actual site, but represents the old Palace, which itself lay on lower ground. 


\section{REFERENCES.}

Ordnance Survey Map, New Series, Sheet 269.

Geological Survey Map, Sheet 8.

1847. PRestwiCh, J.- " Papers on the London Clay and Bagshot Beds." 'Quart. Journ. Geol. Soc.,' Vol. iii, pp. 354, 378.

1872. Whitaker, W.- "Geology of the London Basin." "Geol. Survey Mem.' pp. 315.

1886. Hudlesston, W. H.- "On a recent Section through Walton Common, exposing the London Clay, Bagshot Beds, and Plateau Gravel." 'Quart. Journ. Geol. Soc.,' Vol. xlii, p. 147 (May).

\section{EXCURSION TO DUNGENESS, RYE, AND HASTINGS.}

Whit-Monday and Tuesday, June 14th and 15th, 1886.

Directors: The President, J. E. H. Peyton, F.G.S, and Geo. Wilks.

MondaY.-(Report by The Presidents.)

The chief object of this Excursion was to study the coastchanges and the recent marine deposits of Romney Marsh and its borders. The north-eastern side of the Marsh was visited by the Association at Easter, 1883.

In no part of England have coast-changes been more interesting and important than here. Romney Marsh is defended from the sea partly by natural shingle-banks, partly by sea-walls and embankments : it has been reclaimed at various periods, the northern half (Romney Marsh properly speaking) by the Romans. A small area north-west of Lydd was "inned" about 774, the rest at various dates from 1162 to 1661 . The shingle lies in ridges or "fulls," each marking an old high-water line. These fulls trend in various directions; they truncate each other, and are sometimes cut off at right angles by the existing shore-line.

The shingle at Lydd was probably the shore-line in Roman times; since then the shingle-point has advanced towards the south-east, four miles seawards, in a direct line. The southwesterly extension of the Lydd "fulls" are cut off by the modern coast-line, which is still receding. These old fulls stretched to the south-west, probably joining the nuainland at Fairlight, broken only by one of the outlets of the Rother. This mass of shingle (and the old Marsh behind it) was subsequently denuded, its pebbles going to form the accumulation at Dungeness. The sea encroached to the old cliff at Winchelsea and Rye, but in later 